\title{
Aufsätze
}

weakness and transcurrent faulting separating them. Block faulting may have enhanced mountain elevation, and the mountains themselves continued to be a major source of sediment supply, nurturing important mountain glaciers during the Late Proterozoic Era. Seas surrounded the mountain chains and invaded the intermountain "low" between them. Basaltic volcanic activity immediately preceded glaciation and the escaping lavas may have issued by faults bounding local crustal mountain blocks.

Some 10,000 feet of sediments accumulated in Sturtian times, and strong deformation occurred probably during the Cambrian period. Block faults with east-west or W.N.W.-E.S.E. strike tendencies were active, and controlled the folding which developed with markedly east-west axes. Basement horsts (e.g. Granite Downs) controlled the broader anticlines or anticlinoria, and grabens cradled the synclines or synclinoria; a series of subparallel folds with steeply dipping limbs were developed through this mechanism. Uplift, deep erosion and finally peneplanation were well advanced by Ordovician times.

\section{Ordovician Structure}

Crustal downwarping, possibly assisted by graben faulting, provided access for Ordovician seas. Much of the negative zone south of the Everard Ranges, previously occupied by Upper Proterozoic seas was again inundated. The strongly east-west alignment of the fold basins is completely preserved, and the measure of local basement block faulting is apparent from the abrupt change from flat dips to steep and sometimes vertical disposition of major fold limbs.

\section{Acknowledgements}

The geological investigations basic to this work were carried out by the authors originally as officers of the South Australian Geological Survey and later during various economic exploration projects operated by Geosurveys of Australia Limited on behalf of clients.

Permission to publish information gained while officers with the Geological Survey is greatly appreciated.

\section{References}

InNEs, M. J. S., 1957: Gravity and Isostacy in Central Quebec. American Geophysical Union 38 (2). - Sprigg, R. C., and Wilson, R. B.: Geological Map sheets "Indulkana", "Kenmore", "Giles" and "Ernabella". S. A. Geological Survey. - Wilson, A.F., 1947: The Charnockitic and Associated Rocks of North Western South Australia. Trans. Roy. Soc. S. A. 71.

\section{Errata}

On the accompanying coloured map, the meridians should be numbered $130^{\circ}$ to $133^{\circ}$ and the black circle S. of Mt. Cuthbert should be marked "Ernabella". 


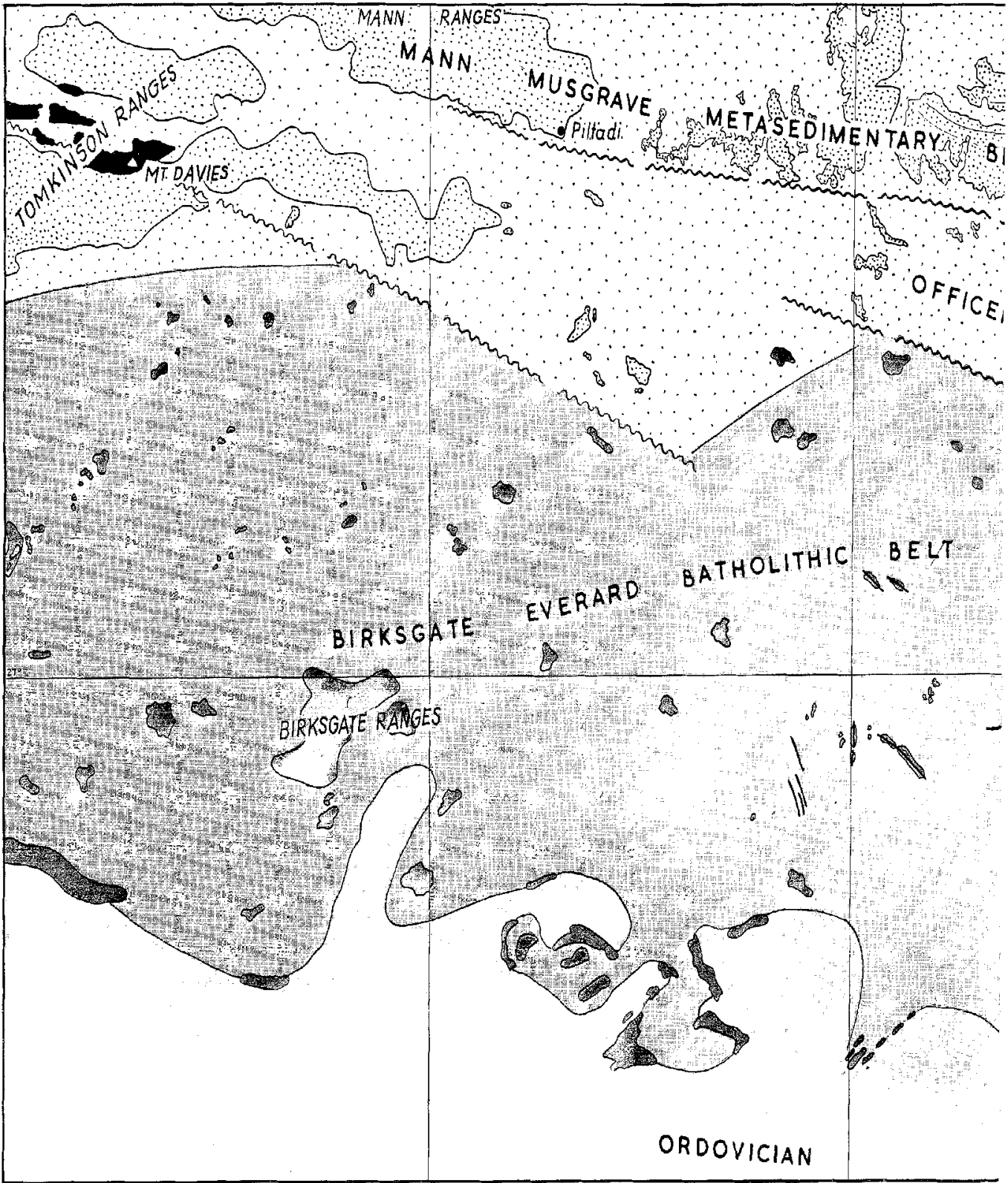

\section{LEGEND}

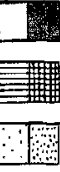

Ordovician Sediments

Upper Proterozoic Sediments

Archaean Metasediments
Ciles Complex of Basics \& Uirrabasics

Archazan Massive Cranite

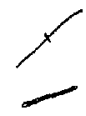

Fold axes

Dolerite dykes

mone Major Faults 


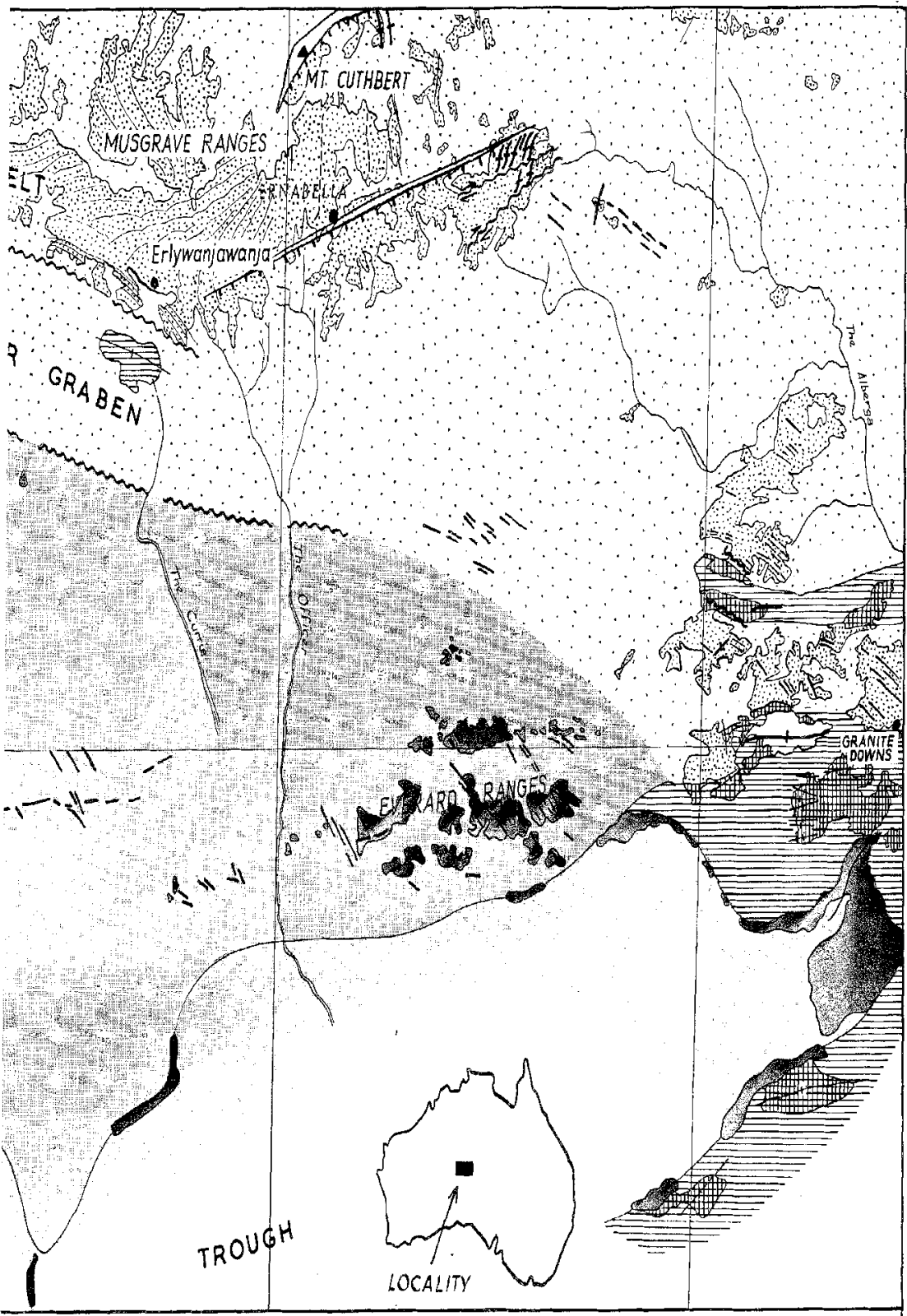

\section{MUSGRAVE MOUNTAIN PROVINCE \\ SOUTH AUSTRALIA \\ SHOWING}

MAJOR STRUCTURAL FEATURES 